\title{
ЧЕРЕПАШИЙ КАРАПАКС КАК ПРИМЕР ПОЛИГОНАЛЬНОГО РАЗБИЕНИЯ
}

Войтеховский Ю.Л. ${ }^{1,2}$, Степенщиков Д.Г. ${ }^{2}$

${ }^{1}$ Санкт-Петербургский Горный университет, Санкт-Петербург, voytekhovskiy_yul@pers.spmi.ru

2 Геологический институт КНЦ РАН, Апатиты, stepen@geoksc.apatity.ru

\section{Аннотация}

В ряде статей авторы уже рассматривали закономерности полигональных разбиений плоских, квази-плоских (слегка изогнутых) и квази-сферических поверхностей в минеральной и живой природе. Во всех примерах поражает, сколь разнообразно природа использует оптимальные решения, как в минеральных и живых объектах упрятаны геометрические инварианты пространства вложения, как в онтогенезе и филогенезе случайное борется с закономерным, поливариантность - с предопределённостью. Ранее речь шла о кристаллах, фуллеренах, вирусах, радиоляриях, вольвоксах, колючих и пластинчатых рыбах [3-6, 8, 17-21]. В этой статье рассматриваются черепахи (лат. Testudines) - отряд пресмыкающихся, живущих уже 250 млн. лет, включающий около 230 видов, группируемых в 12 семейств и 5 подотрядов, распространённых по всей Земле: на суше, в пресных и солёных водоёмах.

\section{Проблема}

В чём состояла закономерность и в чём - случайность при формировании полигонального разбиения карапакса в эволюции черепах? «У всех черепах количество костных пластинок карапакса превышает таковое на пластроне. Например, Plesiochelye, Mauremys, Testudo, Melanochelys имеют в карапаксе до 50, а в пластроне 9 пластинок. Соотношение этих пластинок составляет, соответственно: у Eusarkia 39 и 11, у Trionyx 25 и 9, у Kinosternon 44 и 8, у Archelon 52 и 7 и т.д. Специальные измерения отдельных элементов панциря черепах разного возраста показали, что все пластинки растут в онтогенезе относительно равномерно и нарастают по периферии в области швов. Пропорциональный рост отдельных частей панциря обеспечивается мозаичностью его строения. Функциональное значение наличия в карапаксе относительно большего, чем в пластроне, числа костных элементов мы видим в обеспечении постоянства выпуклости свода спинного щита. <..> Очевидно, в связи с отмеченными особенностями варьирования мозаичности строения костной основы панциря черепах комплекс роговых щитков также подвергался в ходе эволюции изменениям» [14].

От числа пластин зависит выпуклость карапакса, то есть его вместимость и прочность, обеспечивающие жизненно важные потребности вида. Добавим двустороннюю симметрию карапакса как следствие принципа, известного в минералогии и биологии: макроформа индивида формируется как компромисс внутренних потребностей и внешних условий. Как биологическое следствие, все организмы, приспосабливающиеся к движению в поле тяжести по поверхности Земли, приобретают в онтогенезе и филогенезе двустороннюю симметрию $[2,7,15,16]$. Вполне определилась задача 
компьютерного моделирования: для черепахи (рис. 1) и её сородичей (геометрия панциря при взрослении особи не меняется) найти все возможные разбиения центральной части карапакса (она формируется независимо от периферийного пояса) на 4-, 5- и 6-угольные пластины общим числом 13 (для другого вида его следует изменить), контактирующие по 3 в точке. Подчеркнём, что нас интересует комбинаторика разбиений, а не их метрика [9]. Насколько разнообразны искомые разбиения и насколько распространены среди них двусторонне-симметричные?

\section{Решение}

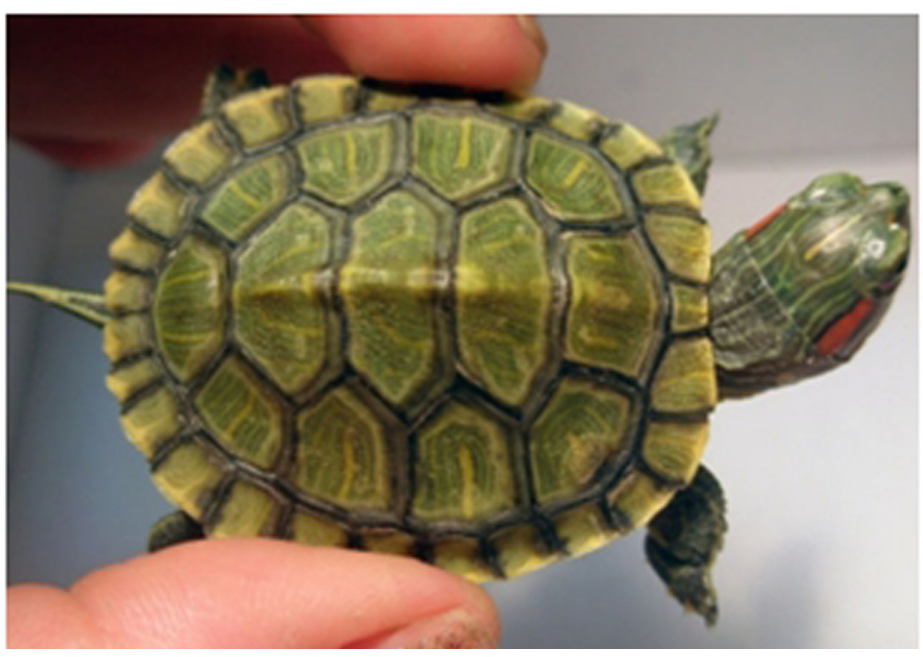

Рис. 1. Предмет компьютерного моделирования - чентральная часть карапакса пресноводной красноухой черепахи.
Компьютерным моделированием найдено полное число разбиений карапакса 13-ю 4-, 5- и 6-угольными пластинами при условии, что его внешний периметр содержит не менее 6 сторон. Всего таких разбиений 426 (рис. 2, табл.), из них двустороннесимметричных 114, в том числе с «избыточной» симметрией (более одной плоскости симметрии) 14 (рис. 3): \#\# $1(6 \mathrm{~mm}) ; 13,32,90,189$, 196, 300, 359, 396, 419, 426

$(m m 2) ; 301(4 m m) ; 330,383(3 m)$. Среди них - карапакс пресноводной красноухой черепахи (\# 396).

Таблица. Группы симметрии для разбиений карапакса (см. рис. 2).

Асимметричные формы не указаны.

\begin{tabular}{|c|c|c|}
\hline $\begin{array}{l}\text { Точечная } \\
\text { группа } \\
\text { симметрии }\end{array}$ & Номера разбиений & Всего \\
\hline$m$ & $\begin{array}{l}\text { 2,9-12,16-18,29-31,57-62,80-84,86-89,149-157,180- } \\
188,191,192,242-250,291-299,321-324,329,333-337,353- \\
358,376-382,394,395,398,399,401-404,408,409,418,424,425\end{array}$ & 100 \\
\hline 2 & $28,85,179,352$ & 4 \\
\hline$m m 2$ & $13,32,90,189,196,300,359,396,419,426$ & 10 \\
\hline $3 m$ & 330,383 & 2 \\
\hline $4 m m$ & 301 & 1 \\
\hline $6 \mathrm{~mm}$ & 1 & 1 \\
\hline
\end{tabular}




\section{Обсуждение}

Итак, природе было из чего выбирать. 114 двусторонне-симметричных вариантов - четверть от общего числа - немало в абсолютном и относительном выражениях. Остальные 312 вариантов природой забракованы, ведь двигаться в тяжёлом асимметричном (или всего с одной поворотной осью 2-го порядка) карапаксе неудобно - будет заносить влево или вправо. И это совсем не то, что нужно для выживания вида. Вспомним и про широко распространённый биологический энантиоморфизм (диссимметрию, по Л. Пастеру). Представим, как по Галапагосам кружат гигантские черепахи - все по или против часовой стрелки. Одним словом, зеркально-асимметричные карапаксы определённо не способствуют эволюции вида. Но ведь эта правда выяснилась и закрепилась в генотипе не сразу. Что известно о перипетиях внутривидового отбора? О чём говорят аномалии развития?

«В 1968 г. в Ваилованском заповеднике найден экземпляр средиземноморской черепахи с увеличенным числом вертебральных щитков (8 вместо 5). I и V щитки - без изменения, II, III и IV - удвоены и расположены в два ряда. Отклонения от нормы в числе и форме щитков карапакса встречались и у других экземпляров с.ч. в Вашлованской котловине. Чаще всего II-го, реже III-го щитка, что выражалось в удвоении их числа, щитки были неправильной формы. Частота встречаемости таких экземпляров в Вашлованской котловине выше, чем по остальному ареалу в Грузии. В 1970 г. В.М. Чхиквадзе найдена с.ч. с идентичным расположением щитков в 20 км от первой находки. В 1988 г. в ТГУ доставлена с.ч. с таким же числом и расположением щитков из окрестностей Тбилиси. Отклонения от нормы в щитках карапакса с.ч. отмечены Алекперовым и Хозацким (1971), но они воздержались от суждения о причинах аномалий. Идентичная изменчивость щитков карапакса отмечена у с.ч. (Брушко, Кубыкин, 1980; Стальмакова, Харлампиди, 1987) и для болотной, средиземноморской и степной (Черепанов, 1987). Последний считает её результатом нарушений в эмбриональной стадии. Мы имеем дело с гомологичной аномалией у различных видов черепах, причины которой требуют изучения» [1].

«Исходя из морфогенетических данных, весь спектр изменчивости щитков панциря черепах обусловлен нарушениями эмбрионального развития: асимметричная закладка контралатеральных эпидермальных плакод со сдвигом на сегмент или более, закладка дополнительных плакод в «свободных» септальных углублениях, атипичное слияние соседних эпидермальных плакод, отсутствие закладки регулярных эпидермальных плакод в типичных сегментах тела» (рис. 4) [10-13].

Наконец, почему природа предпочла не просто двустороннесимметричный $(m)$, а избыточно симметричный ( $m m 2)$ вариант карапакса? Образно говоря, эта симметрия была бы черепахе «как раз впору», если бы она могла покидать тяжёлый карапакс (как рак-отшельник - раковину) или разворачиваться внутри него, экономя силы на разворотах, ради движения 


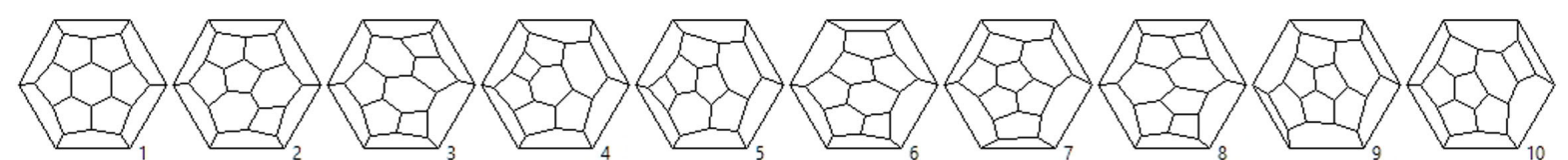

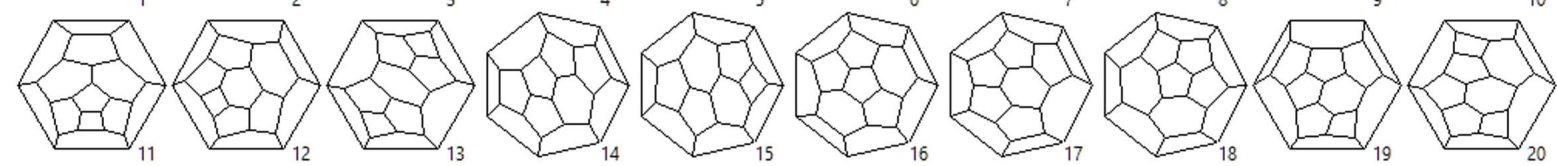

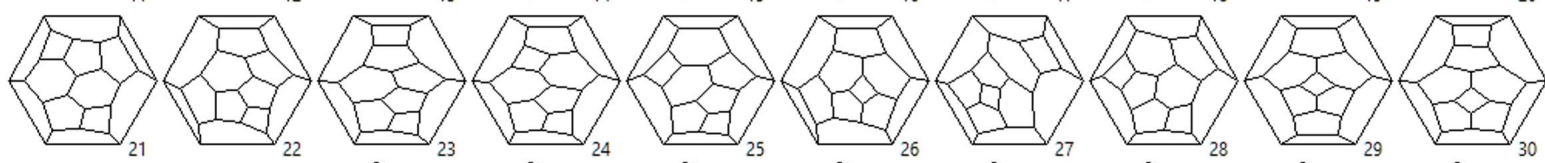

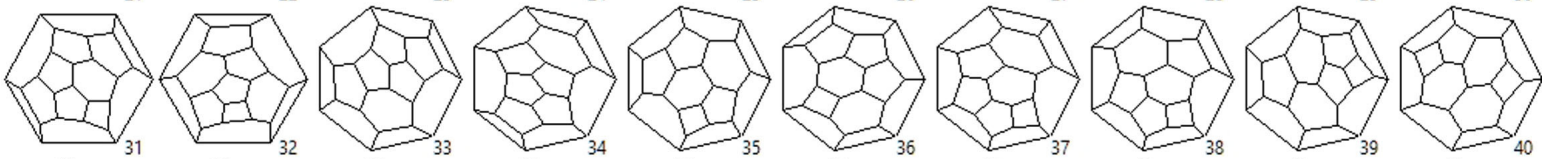
(a)

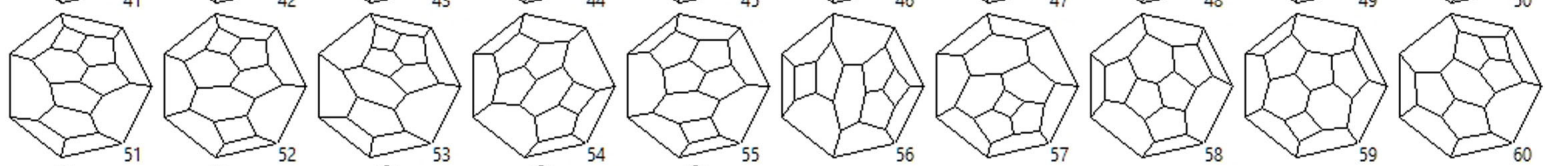

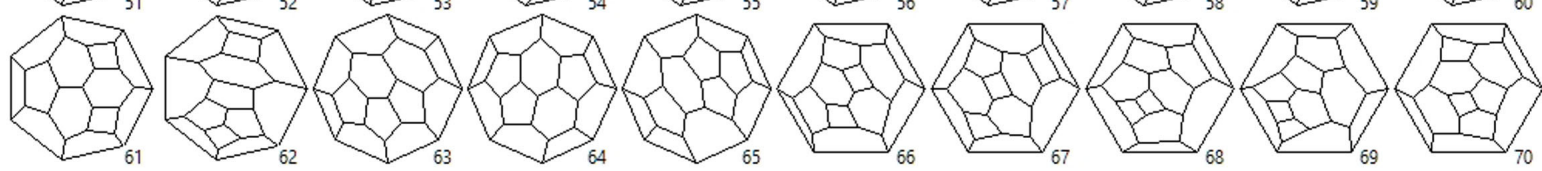

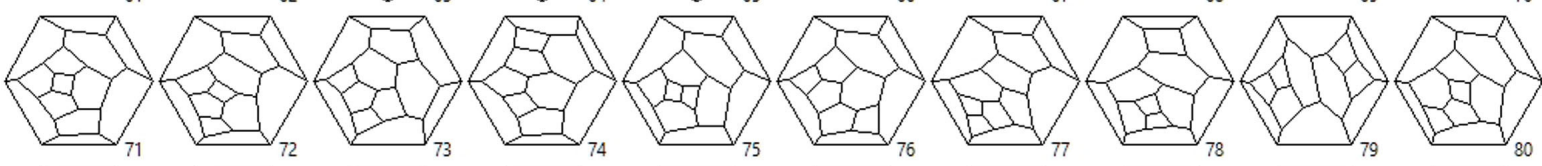

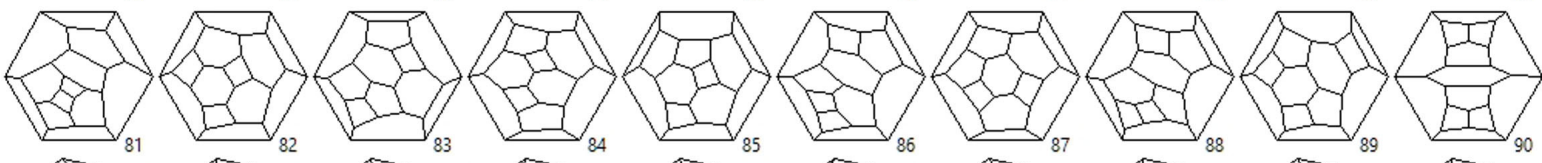

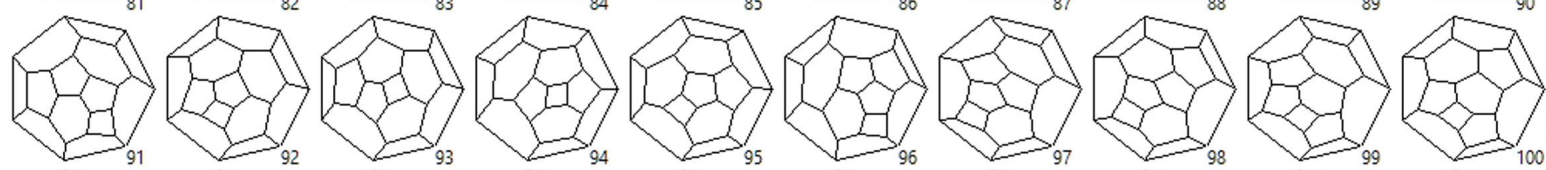
[3.

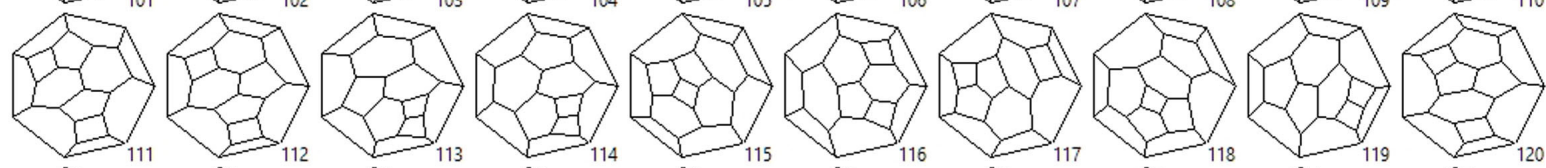

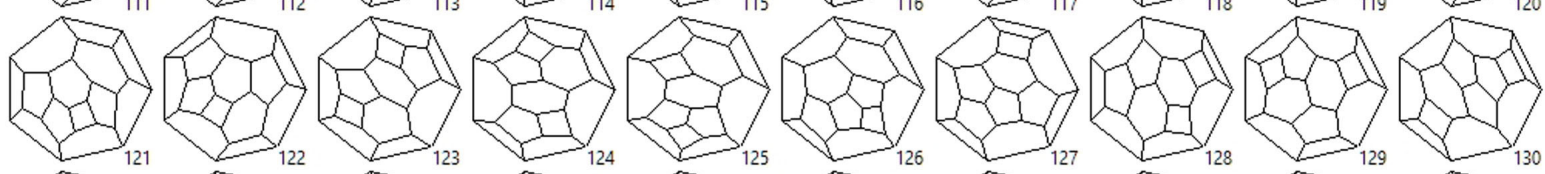

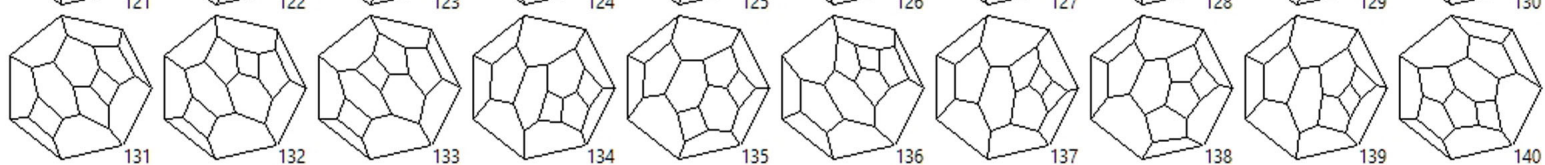

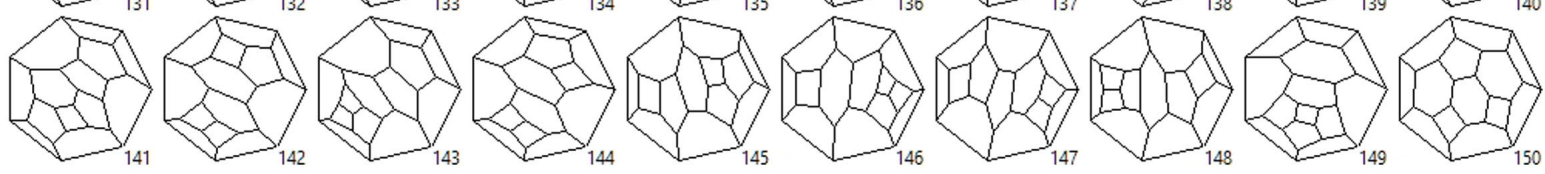

Рис. 2. Разбиения карапакса. Пояснения в тексте. 
Paris (3) 37 .

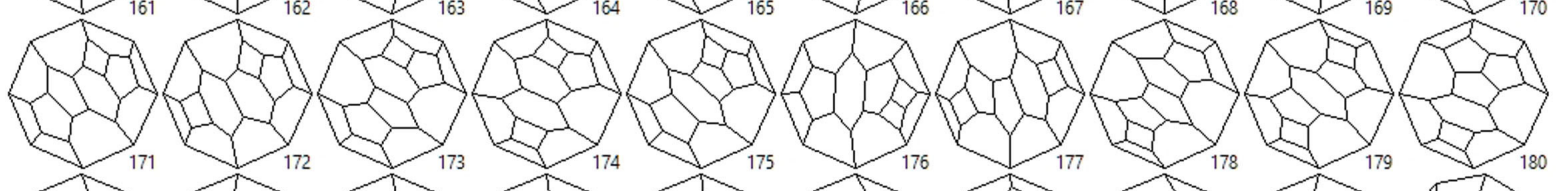
(153)

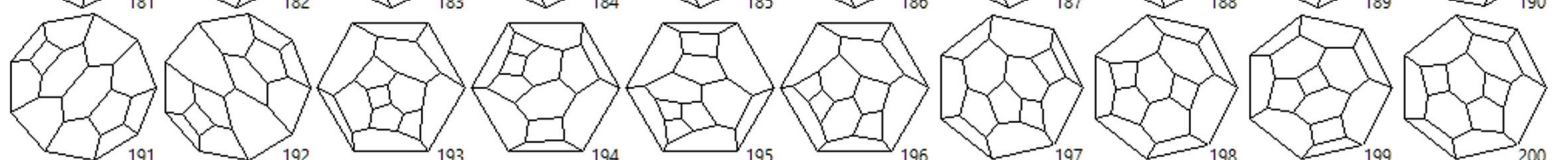
Fis

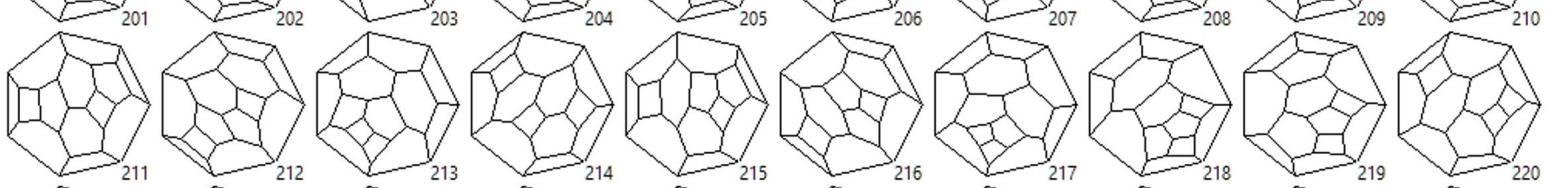

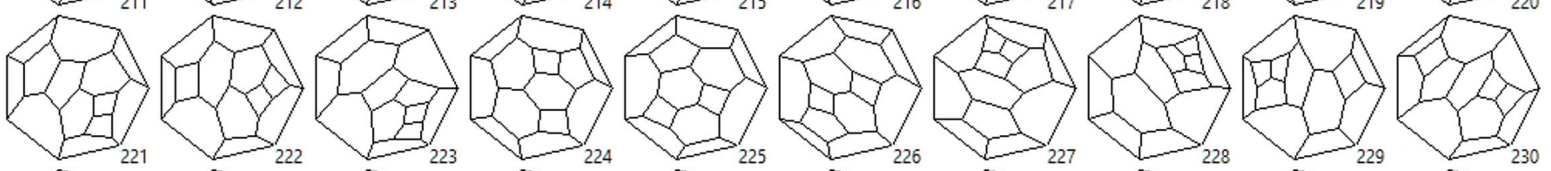
237.

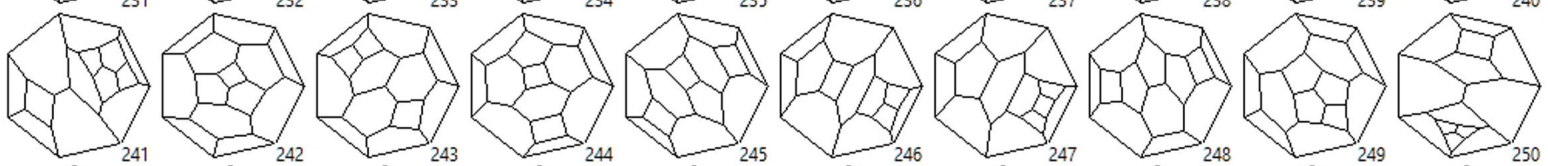
(5) 353 .

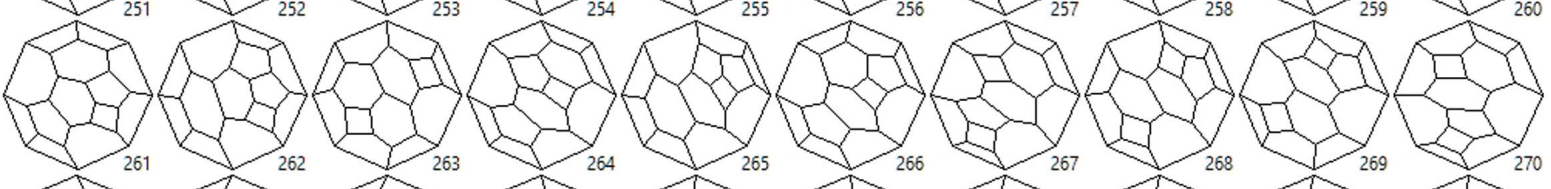

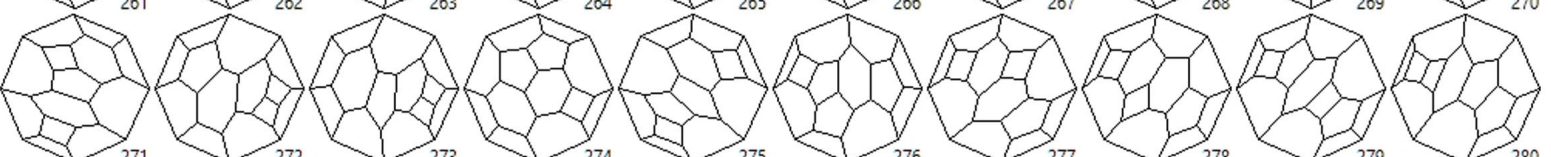

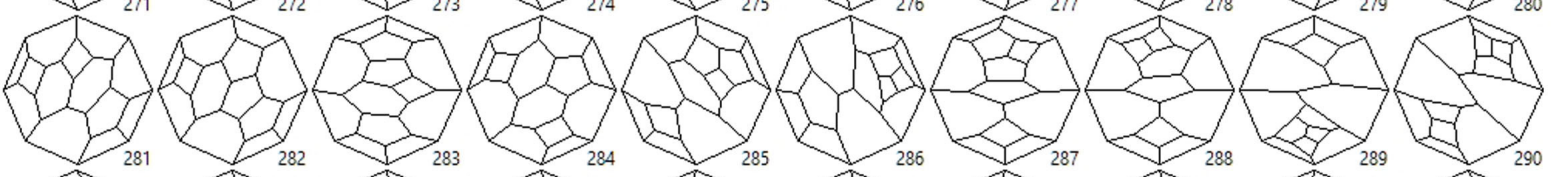
5.

Рис. 2. (продолжение). 


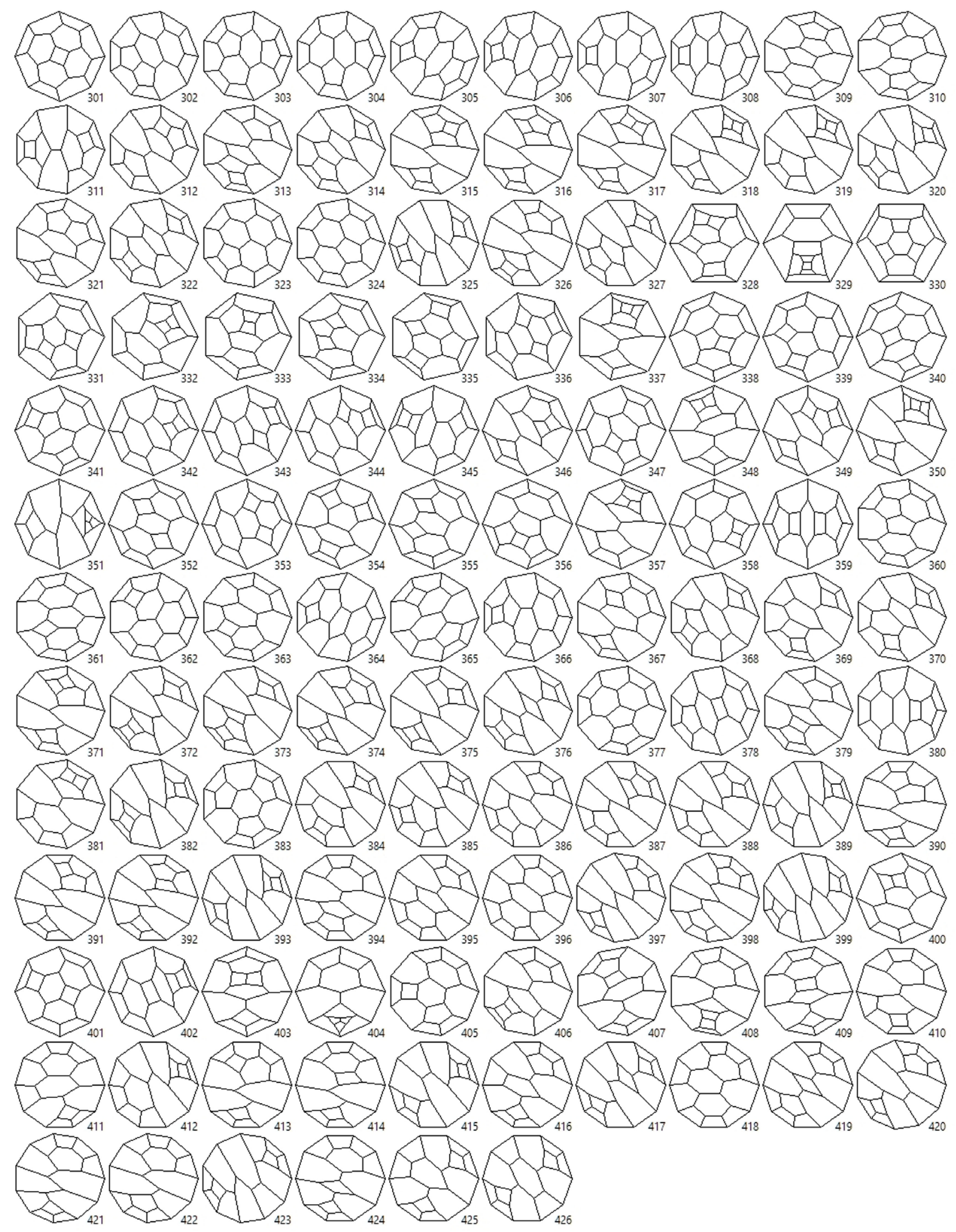

Рис. 2. (окончание).

в двух перпендикулярных направлениях, причём в обе стороны. Ещё больше возможностей дали бы варианты $3 \mathrm{~m}, 4 \mathrm{~mm}$ и $6 \mathrm{~mm}$. Почему выбран простейший из избыточных вариантов, но и тот не использован в полной мере? Или они были опробованы природой, но оказались не оптимальными? Почему бы не пофантазировать о будущих сенсационных палеонтологических находках! 

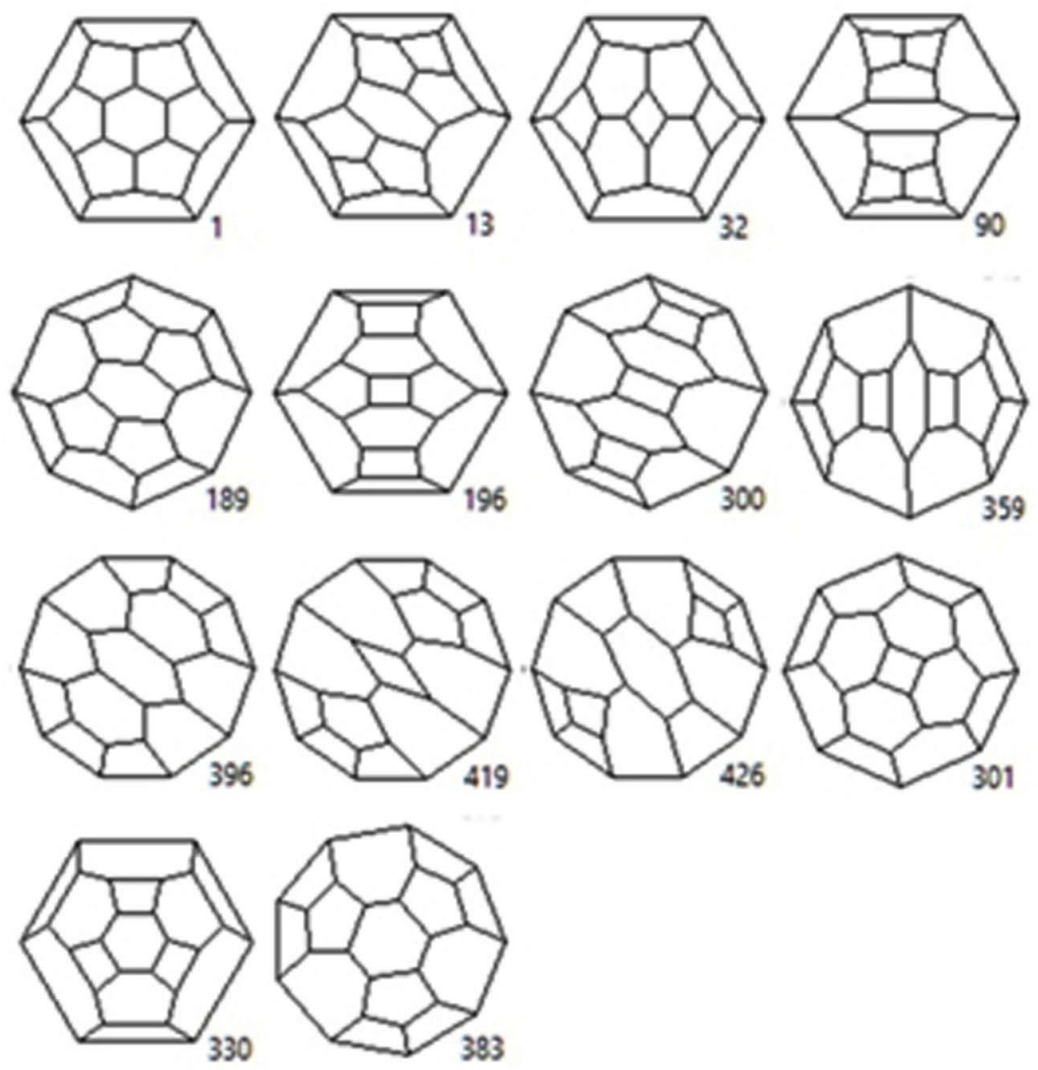

Рис. 3. Разбиения карапакса с избыточной симметрией.
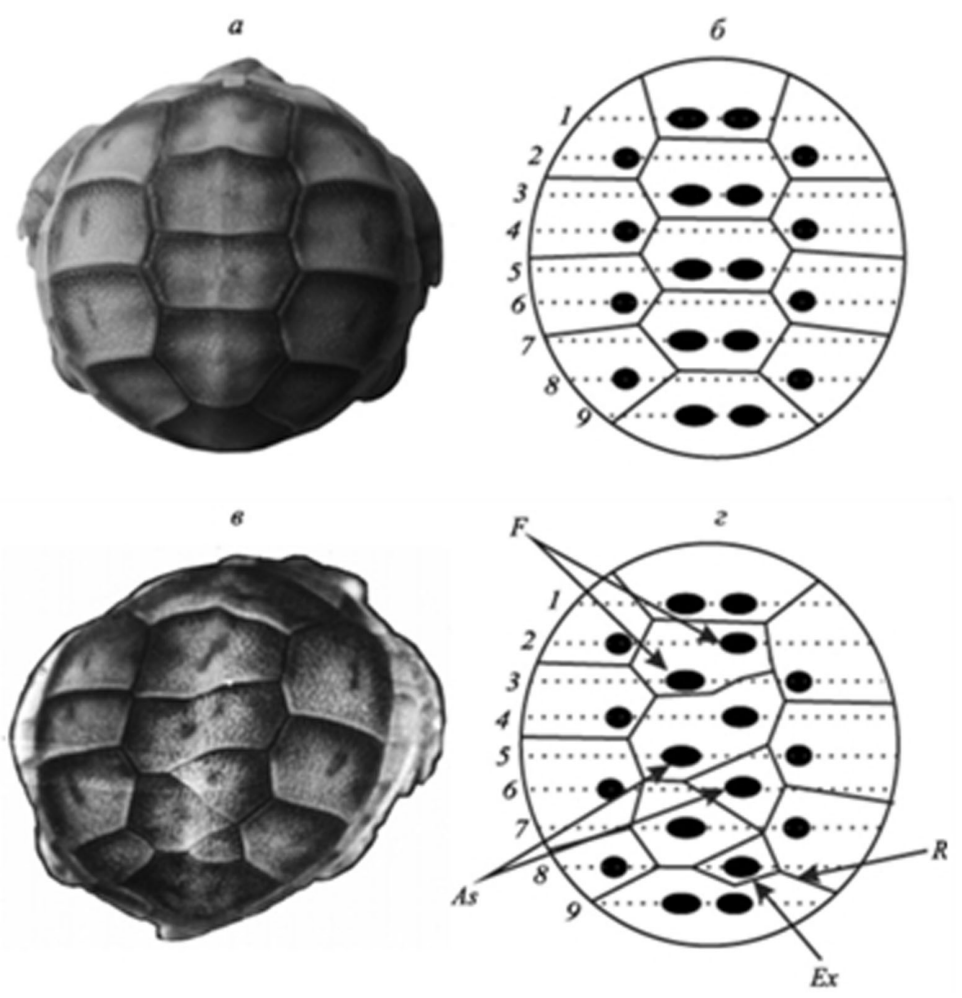

Рис. 4. Правильное (вверху) и неправильное (внизу) формирование карапакса [13]. 


\section{Заключение}

В биологии черепах известно очень многое. Но представляется, что оппозиция случайного и закономерного в филогенезе и онтогенезе изучена не до конца. С точки зрения математика, черепахи - это бегающие и плавающие решения некоторого фундаментального диофантова уравнения, сводящегося для каждого вида к своему характеристическому уравнению (это лишь отчасти метафора, так как перечисление разбиений карапакса на определённые полигоны подразумевает решение диофантовых уравнений). Если угодно, они суть аристотелевы реализации некоторой платоновой идеи карапакса - удивительной структуры среди других совершенных созданий природы. В какой мере полигональное и симметричное строение карапакса определено стилем движения черепах и закреплено эволюцией, а в какой содержит инвариант случайного разбиения фрагмента квази-плоской поверхности? Здесь открывается захватывающая перспектива исследований на стыке биологии развития и математического моделирования.

\section{Список литературы}

1. Бакрадзе М.А., Пицхвлаури В.П. Интересная морфа средиземноморской черепахи // Вопросы герпетологии. К.: Наук. Думка. 1989. С. 20.

2. Беклемишев В.Н. Основы сравнительной анатомии беспозвоночных. М.: Наука. 1964. Т. 1.432 с. Т. 2. 448 с.

3. Войтеховский Ю.Л. О морфологическом разнообразии колоний Pandorina morum (Müll.) Bory (Volvocaceae) // Ж-л общ. биол. 2001. Т. 62. № 5. C. 425-429. 4. Войтеховский Ю.Л. О кристаллах, полиэдрах, радиоляриях, вольвоксах, фуллеренах и немного - о природе вещей // Природа. 2004. № 8. С. 19-24.

5. Войтеховский Ю.Л. О кристаллах, полиэдрах, радиоляриях, вольвоксах, фуллеренах и немного - о природе вещей // Российская наука: нам гранты думать и жить помогают. М.: Октопус-Природа. 2004. С. 208-217.

6. Войтеховский Ю.Л. Геометрические мотивы в морфологии рыб Tetraodontiformes // Ж-л общ. биол. 2009. Т. 70. № 3. С. 257-261.

7. Войтеховский Ю.Л. Доступно и точно о принципе диссимметрии Кюри // Природа. 2010. № 6. С. 19-23.

8. Войтеховский Ю.Л., Тимофеева М.Г., Степенщиков Д.Г. Принцип Кюри и морфологическое разнообразие колоний Pandorina morum (Müll.) Bory (Volvocaceae) // Ж-л общ. биол. 2006. Т. 67. № 3. С. 206-211.

9. Киладзе А.Б. Морфологическая геометрия карапакса различных экологических форм черепах. М.: РУСАЙНС. 2017. 194 с.

10. Черепанов Г.О. Формирование мозаики роговых щитков панциря черепах // Зоол. ж-л. 1987. Т. 66. № 9. С. 1339-1348.

11. Черепанов Г.О. Аномалии костного панциря черепах // Зоол. ж-л. 1994. T. 73. № 6. C. 68-78.

12. Черепанов Г.О. Панцирь черепах: происхождение и развитие в онто- и филогенезе. Автореф. дис. уч. ст. д.б.н. СПб.: СПбГУ. 2004. 34 с. 
13. Черепанов Г.О. Изменчивость щитков панциря черепах: закономерности морфогенеза и природа аномалий // Вестник СПбГУ. Сер. 3. Биология. 2016. № 3. С. 170-174.

14. Чхиквадзе В.М. Мозаичность строения и особенности роста панциря черепах // Вопросы герпетологии. К.: Наук. Думка. 1973. С. 273.

15. Шафрановский И.И. Симметрия в природе. Л.: Недра. 1985. 168 с.

16. Curie P. Sur la symétrie dans les phénomènes physiques, symétrie d'un champ électrique et d'un champ magnétique // J. Physique. Paris. 1894. N. 3. P. 393-415. 17. Voytekhovsky Yu.L. On the exotic fishes given to ... geometry // Nature Precedings. 2008. <http://hdl.handle.net/10101/npre.2008.2191.1>

18. Voytekhovsky Yu.L. Symmetry, asymmetry, dissymmetry and enantiomorphism of the polyhedral forms // Paleont. J. 2014. V. 48. N. 11. P. 1137-1142. 19. Voytekhovsky Yu.L. Biomineral analogues in ontogeny and phylogeny // Paleont. J. 2015. V. 49. N. 14. P. 1-7.

20. Voytekhovsky Yu.L. Homological series of icosahedral viruses and fullerenes // Paleont. J. 2016. V. 50. N. 13. P. 1505-1509.

21. Voytekhovsky Yu.L., Stepenshchikov D.G. Fullerene transformations as analogues of radiolarian skeleton microevolution // Paleont. J. 2016. V. 50. N. 13. P. 1544-1548. 